\title{
Multi-stage antimony mineralization in the Banxi Sb deposit, South China
}

\author{
HUAN LI ${ }^{1}$
}

${ }^{1}$ School of Geosciences and Info-Physics, Central South

University, Changsha 410083, China, lihuan@csu.edu.cn

Arsenopyrite Re-Os dating of the first quartz-arsenopyrite stage alteration zones, quartz $\mathrm{Rb}-\mathrm{Sr}$ dating of the second quartz-stibnite stage ores, and stibnite/arsenopyrite $\mathrm{Rb}-\mathrm{Sr}$, $\mathrm{Sm}-\mathrm{Nd}$ and zircon (U-Th)/He dating of the third stibnite stage ores and alteration zones were carried out to constrain the multiple mineralizaiton events at the Banxi Sb deposit, South China. The arsenopyrite Re-Os analysis yielded an approximate isochron age of $\sim 450 \mathrm{Ma}\left(\mathrm{n}=5 ;{ }^{187} \mathrm{Re}=0.015\right.$ $\left.0.51 \mathrm{ppb} ;{ }^{187} \mathrm{Os}=0.0012-0.0052 \mathrm{ppb}\right)$. Six quartz samples show variable $\mathrm{Rb}(0.02206-3.642 \mathrm{ppm})$ and $\mathrm{Sr}(0.5354-2.505$ ppm) compositions, with ${ }^{87} \mathrm{Rb} /{ }^{86} \mathrm{Sr}$ and ${ }^{87} \mathrm{Sr} /{ }^{86} \mathrm{Sr}$ ratios ranging from 0.119 to 4.93 and from 0.72663 to 0.74002 , respectively. The ${ }^{87} \mathrm{Rb} /{ }^{86} \mathrm{Sr}$ and ${ }^{87} \mathrm{Sr} /{ }^{86} \mathrm{Sr}$ values of the quartz samples yielded an $\mathrm{Rb}-\mathrm{Sr}$ isochron age of $196 \pm 4 \mathrm{Ma}(1 \sigma$, MSWD $=0.70$ ), with an initial ${ }^{87} \mathrm{Sr} /{ }^{86} \mathrm{Sr}$ value of $0.72640 \pm$ $0.00011(1 \sigma)$. The $\mathrm{Rb}-\mathrm{Sr}$ and $\mathrm{Sm}-\mathrm{Nd}$ isotopic analyses of the stibnite and arsenopyrite yield isochron ages of $129.4 \pm 2.4$ $\mathrm{Ma}(2 \sigma, \mathrm{MSWD}=1.3)$ and $130.4 \pm 1.9 \mathrm{Ma}(2 \sigma, \mathrm{MSWD}=1.6)$, respectively. The ${ }^{87} \mathrm{Rb} /{ }^{86} \mathrm{Sr}$ and ${ }^{87} \mathrm{Sr} /{ }^{86} \mathrm{Sr}$ ratios of the sulfides are $0.3016-3.538$ and $0.711463-0.717591$, respectively for stibnite, and 0.2251-2.214 and 0.711244-0.711565, respectively for arsenopyrite. The ${ }^{147} \mathrm{Sm} /{ }^{144} \mathrm{Nd}$ and ${ }^{143} \mathrm{Nd} /{ }^{144} \mathrm{Nd}$ ratios are $0.1174-0.9816$ and $0.511942-0.512768$ for stibnite, with $\varepsilon N d(t)$ values $(t=130 \mathrm{Ma})$ ranging from -12.4 to -6.6 , and two-stage model ages ( $\mathrm{T}_{2 \mathrm{DM}}$ ) ranging from 1457 to $1932 \mathrm{Ma}$. The (U-Th)/He ages from all zircon crystals are in the range of 101.5-139.9 Ma. Thirteen zircon grains from a ore sample yielded a mean $(\mathrm{U}-\mathrm{Th}) / \mathrm{He}$ age of $126.0 \pm 4.9 \mathrm{Ma}(\mathrm{MSWD}=1.0)$, and twenty zircon grains from a alteration zone wall rock yielded a mean $(\mathrm{U}-\mathrm{Th}) / \mathrm{He}$ age of $122.2 \pm 5.4 \mathrm{Ma}(\mathrm{MSWD}=1.4)$. The two mean ages are consistent within error, and all the thirty-three zircons combined yielded a mean (U-Th)/He age of $123.8 \pm 3.8 \mathrm{Ma}$ $(\mathrm{MSWD}=1.2)$. All of these ages reported in this study are roughly consistent with those of the $\mathrm{Sb}(\mathrm{Au})$ deposits within and around the Jiangnan Orogen: 435-380 Ma, 230-200 Ma and 160-130 Ma.

Consequently combined with geochemcal studies, a threeperiod genetic model has been proposed for the world-class $\mathrm{Sb}$ mineralization in the central-western Hunan region, assocaited with the Caledonian (Cambrian-Silurian) Orogeny, Indosinian (Triassic) Orogeny and Yanshanian (Late Jurassic-Early Cretaceous) magatic event, respectively. 